Meijer, A., Jonges, M., Abbink, F., Ang, W., Beek, J. van, Beersma, M., Bloembergen, P., Boucher, C., Claas, E., Donker, G., Gageldonk-Lafeber, R. van, Isken, L., Jong, A. de, Kroes Leenders, S., Lubben, M. van der, Mascini, E., Niesters, B., Oosterheert, J.J., Osterhaus, A., Riesmeijer, R., Riezebos-Brilman, A., Schutten, M., Sebens, F., Stelma, F., Swaan, C., Timen, AIVE Veen, A. van 't, Vries, E. van der, Wierik, M. te, Koopmans, M. Oseltamivir-resistant pandemic $A(H 1 N 1) 2009$ influenza viruses detected through enhanced surveillance in the Netherlands, 2009-2010. Antiviral Research: 2011, 92(1), 81-89

\begin{tabular}{l|l}
$\begin{array}{l}\text { Postprint } \\
\text { Version }\end{array}$ & 1.0 \\
Journal website & http://www.sciencedirect.com/science/article/pii/S0166354211003718 \\
\hline Pubmed link & $\underline{\text { http://www.ncbi.nlm.nih.gov/pubmed/21767571 }}$ \\
\hline DOI & $10.1016 /$.antiviral.2011.07.004
\end{tabular}

This is a NIVEL certified Post Print, more info at http://www.nivel.eu

\title{
Oseltamivir-resistant pandemic A(H1N1) 2009 influenza viruses detected through enhanced surveillance in the Netherlands, 2009-2010
}

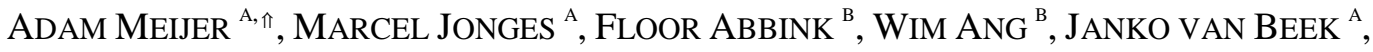 \\ Matthias Beersma ${ }^{\mathrm{C}}$, Peter Bloembergen ${ }^{\mathrm{D}}$, ChARles Boucher ${ }^{\mathrm{C}}$, ERIC ClaAs ${ }^{\mathrm{E}}$, GÉ \\ DONKER $^{\mathrm{F}}$, RIANNE VAN GAGELDONK-LAFEBER ${ }^{\mathrm{A}}$, LESLIE ISKEN ${ }^{\mathrm{A}}$, ARJAN DE JONG ${ }^{\mathrm{G}}$, ALOYS \\ KROES ${ }^{\mathrm{E}}$, SANDER LEENDERS ${ }^{\mathrm{H}}$, MARIKEN VAN DER LUBBEN ${ }^{\mathrm{A}}$, ELLEN MASCINI ${ }^{\mathrm{I}}$, BERT \\ NIESTERS ${ }^{\mathrm{J}}$, JAN JELRIK OOSTERHEERT ${ }^{\mathrm{K}}$, ALBERT OSTERHAUS ${ }^{\mathrm{C}}$, ROB RIESMEIJER ${ }^{\mathrm{A}}$, \\ ANNELIES RIEZEBOS-BRILMAN ${ }^{\mathrm{J}}$, MARTIN SCHUTTEN ${ }^{\mathrm{C}}$, FRÉ SEBENS ${ }^{\mathrm{L}}$, FOEKJE STELMA ${ }^{\mathrm{G}}$, \\ CORIEN SWAAN ${ }^{\mathrm{A}}$, AURA TIMEN ${ }^{\mathrm{A}}$, ANNEMARIE VAN 'T VEEN ${ }^{\mathrm{K}}$, ERHARD VAN DER VRIES ${ }^{\mathrm{C}}$, \\ MARGREET TE WIERIK ${ }^{\mathrm{M}}$, MARION KOOPMANS ${ }^{\mathrm{A}, \mathrm{C}}$
}

${ }^{a}$ Center for Infectious Disease Control, National Institute for Public Health and the Environment (RIVM), Bilthoven, The Netherlands

${ }^{\mathrm{b}}$ VU University Medical Center, Amsterdam, The Netherlands

${ }^{\mathrm{c}}$ Erasmus University Medical Center, Rotterdam, The Netherlands

d Isala Clinics, Zwolle, The Netherlands

e Leiden University Medical Center, Leiden, The Netherlands

${ }^{f}$ NIVEL, Netherlands Institute for Health Services Research, Utrecht, The Netherlands

${ }^{g}$ Radboud University Medical Center Nijmegen, Nijmegen, The Netherlands

h Jeroen Bosch Hospital, 's-Hertogenbosch, The Netherlands

'Medical Microbiology and Immunology Laboratory, Rijnstate Hospital, Velp, The Netherlands

j University Medical Center Groningen, Groningen, The Netherlands

${ }^{k}$ University Medical Center, Utrecht, The Netherlands

' Deventer Hospital, Deventer, The Netherlands

${ }^{\mathrm{m}}$ Municipal Health Service Midden-Nederland, Zeist, The Netherlands

\begin{abstract}
A B S T R A C T
Enhanced surveillance of infections due to the pandemic A(H1N1) influenza virus, which included monitoring for antiviral resistance, was carried out in the Netherlands from late April 2009 through late May 2010.

More than 1100 instances of infection with the pandemic A(H1N1) influenza virus from 2009 and 2010 [A(H1N1) 2009] distributed across this period were
\end{abstract}


Meijer, A., Jonges, M., Abbink, F., Ang, W., Beek, J. van, Beersma, M., Bloembergen, P., Boucher, C., Claas, E., Donker, G., Gageldonk-Lafeber, R. van, Isken, L., Jong, A. de, Kroes Leenders, S., Lubben, M. van der, Mascini, E., Niesters, B., Oosterheert, J.J., Osterhaus, A., Riesmeijer, R., Riezebos-Brilman, A., Schutten, M., Sebens, F., Stelma, F., Swaan, C., Timen, Alvel Veen, A. van 't, Vries, E. van der, Wierik, M. te, Koopmans, M. Oseltamivir-resistant pandemic $A(H 1 N 1) 2009$ influenza viruses detected through enhanced surveillance in the Netherlands, 2009-2010. Antiviral Research: 2011, 92(1), 81-89

analyzed. Of these, 19 cases of oseltamivir-resistant virus harboring the $\mathrm{H} 275 \mathrm{Y}$ mutation in the neuraminidase (NA) were detected. The mean $50 \%$ inhibitory concentration $\left(\mathrm{IC}_{50}\right.$ ) levels for oseltamivir- and zanamivir-susceptible A(H1N1) 2009 viruses were 1.4-fold and 2-fold, respectively, lower than for the seasonal A(H1N1) influenza viruses from 2007/2008; for oseltamivir- resistant A(H1N1) 2009 virus the $\mathrm{IC}_{50}$ was 2.9-fold lower. Eighteen of the 19 patients with oseltamivir- resistant virus showed prolonged shedding of the virus and developed resistance while on oseltamivir therapy. Sixteen of these 18 patients had an immunodeficiency, of whom 11 had a hematologic disorder.

The two other patients had another underlying disease. Six of the patients who had an underlying disease died; of these, five had received cytostatic or immunosuppressive therapy. No indications for onward transmission of resistant viruses were found. This study showed that the main association for the emergence of cases of oseltamivir-resistant A(H1N1) 2009 virus was receiving antiviral therapy and having drug-induced immunosuppression or an hematologic disorder. Except for a single case of a resistant virus not linked to oseltamivir therapy, the absence of detection of resistant variants in community specimens and in specimens from contacts of cases with resistant virus suggested that the spread of resistant A(H1N1) 2009 virus was limited. Containment may have been the cumulative result of impaired NA function, successful isolation of the patients, and prophylactic measures to limit exposure.

\section{INTRODUCTION}

On June 11, 2009 the World Health Organization (WHO) declared an influenza pandemic caused by an $\mathrm{A}(\mathrm{H} 1 \mathrm{~N} 1)$ influenza virus previously unknown to the human population (WHO, 2009a).

The virus of swine origin was first detected in Mexico and the United States and began to spread rapidly across the world causing influenza-like illness (ILI) of mild to moderate severity. The initial reports from Mexico indicated a high case-fatality rate; however, as the virus spread globally, the reported case-fatality rate decreased. Nevertheless, the age distribution of affected people was different from the usual Ushaped curve for seasonal influenza, where the very young and the frail elderly are affected most. This distribution more closely resembled the curve seen during the Spanish flu pandemic of 1918/1919, caused by another variant of A(H1N1) virus, also affecting the middle-aged population (Taubenberger and Morens, 2006). As it was not clear at what pace and in which direction the virus would evolve during adaptation to the human host, surveillance was established to monitor critical positions in genes of the $\mathrm{A}(\mathrm{H} 1 \mathrm{~N} 1) 2009$ virus that had been previously associated with increased virulence (Basler and Aguilar, 2008; Neumann et al., 2009; Chutinimitkul et al., 2010; Herfst et al., 2010). In addition to monitoring for a change in virulence, it was considered critical to monitor for the emergence of antiviral resistance (Rungrotmongkol et al., 2009). 
Meijer, A., Jonges, M., Abbink, F., Ang, W., Beek, J. van, Beersma, M., Bloembergen, P., Boucher, C., Claas, E., Donker, G., Gageldonk-Lafeber, R. van, Isken, L., Jong, A. de, Kroes Leenders, S., Lubben, M. van der, Mascini, E., Niesters, B., Oosterheert, J.J., Osterhaus, A., Riesmeijer, R., Riezebos-Brilman, A., Schutten, M., Sebens, F., Stelma, F., Swaan, C., Timen, Milvel Veen, A. van 't, Vries, E. van der, Wierik, M. te, Koopmans, M. Oseltamivir-resistant pandemic $A(H 1 N 1) 2009$ influenza viruses detected through enhanced surveillance in the Netherlands, 2009-2010. Antiviral Research: 2011, 92(1), 81-89

From the analysis of the first virus isolates by Rungrotmongkol et al., it was clear that the pandemic A(H1N1) influenza virus [A(H1N1) 2009] was naturally resistant against the adamantane class of antiviral drugs because of an S31N substitution in the M2 ion-channel protein, but sensitive to the neuraminidase (NA) inhibitors (NAI) oseltamivir and zanamivir. Many countries had been preparing for an influenza pandemic by stockpiling drugs, mainly oseltamivir. Pandemic plans included containment and mitigation strategies that involved the use of these drugs, supported by modeling studies (Meijer et al., 2007; Lee et al., 2009; Mounier-Jack and Coker, 2006; Patel and Gorman, 2009). As pandemic plans were rapidly activated worldwide, the use of oseltamivir increased dramatically, raising concern about the emergence of resistance against oseltamivir in the context of the limited availability of the other NAI, zanamivir, that could be used as an alternative for treatment of severely ill patients (Couzin-Frankel, 2009; Gupta and Padhy, 2010; van den Wijngaard et al., 2009). This concern was also fueled by the unprecedented emergence of oseltamivir-resistant seasonal $\mathrm{A}(\mathrm{H} 1 \mathrm{~N} 1)$ influenza viruses in the years 2007 and 2008 [A(H1N1) 2007/2008] that subsequently replaced the sensitive variant worldwide, indicating that the N1 NA genetic background in principle can acquire resistance mutations without affecting the transmissibility of the virus (Fleming et al., 2009; Meijer et al., 2009a; Lackenby et al., 2008). In the A(H1N1) 2007/2008 influenza virus, preexisting permissive amino acid substitutions in the NA were likely the prerequisite for the emergence of the resistant variant and sustained transmissibility (Bloom et al., 2010). Nevertheless, this development made the influenza specialists more cautious about the risk of wide-spread use of oseltamivir than before.

In The Netherlands, pandemic plans - which included the involvement of oseltamivir treatment and post-exposure prophylaxis in containment and, later on, mitigation strategies - were activated in April 2009 (Hahné et al., 2009; van den Wijngaard et al., 2009). The first case of A(H1N1) 2009 influenza in The Netherlands was identified on April 30, 2009. Simultaneously, the existing virologic surveillance for influenza was enhanced, which included the monitoring of virulence markers and more extensive monitoring for the emergence of antiviral resistance.

This report describes the results of the enhanced surveillance for antiviral resistance and the follow-up analysis of patients who were shedding resistant virus.

\section{MATERIALS AND METHODS}

\subsection{Specimens and clinical data}

Respiratory specimens were obtained from the initial case finding (Hahné et al., 2009), from general-practitioner (GP) sentinel surveillance for influenza-like illness (ILI) and other acute respiratory infections (ARI) (Donker, 2011), from hospitalized patients and deceased patients with suspected A(H1N1) 2009 infections, and from patients whose illness did not resolve with oseltamivir therapy. Specimens were analyzed for A(H1N1) 2009 influenza virus either in the central laboratories at the RIVM, Bilthoven, and Erasmus Medical Center, Rotterdam, the outbreak assistance laboratory network, and, as the pandemic progressed, at other peripheral laboratories 
Meijer, A., Jonges, M., Abbink, F., Ang, W., Beek, J. van, Beersma, M., Bloembergen, P., Boucher, C., Claas, E., Donker, G., Gageldonk-Lafeber, R. van, Isken, L., Jong, A. de, Kroes Leenders, S., Lubben, M. van der, Mascini, E., Niesters, B., Oosterheert, J.J., Osterhaus, A., Riesmeijer, R., Riezebos-Brilman, A., Schutten, M., Sebens, F., Stelma, F., Swaan, C., Timen, Alvel Veen, A. van 't, Vries, E. van der, Wierik, M. te, Koopmans, M. Oseltamivir-resistant pandemic $A(H 1 N 1) 2009$ influenza viruses detected through enhanced surveillance in the Netherlands, 2009-2010. Antiviral Research: 2011, 92(1), 81-89

(Meijer et al., 2009b; van Asten et al., 2009). Basic information was received with each specimen, which included at minimum the gender and age of the patient and the date of specimen collection. For cases of resistant virus, the clinical virologist or treating doctor completed an additional questionnaire, which included questions on the clinical course of the disease; molecular detection and antiviral susceptibility results of all specimens analyzed; antiviral treatment regimen; underlying disease; treatment with drugs with a primary or secondary immunosuppressive effect; possible exposure to infected persons; and possible contacts with influenza-like illness. Municipal and regional health services were involved in tracing cases and contacts and collecting respiratory specimens for virologic analysis.

\subsection{GP-based ILI surveillance}

In The Netherlands, the GP-based sentinel surveillance system for continuous morbidity registration was started in 1970, covering the whole country and representing about $0.8 \%$ of the total Dutch population (Donker, 2011). About 42 sentinel general practices register consultations for ILI, according to the Pel case definition (Pel, 1965). As the total population listed with each practice is known, a consultation rate as a measure of ILI incidence can be calculated.

A consultation rate of 51 per 100,000 population per week has been set as the epidemic baseline threshold, based on historical data following a method described previously (Alonso et al., 2004).

In addition, since 1994 the GPs are asked to take nose swabs and throat swabs for virologic analysis from a random sample of preferably two patients with ILI per week, or if a GP does not encounter ILI patients to take swabs from two patients with another ARI per week.

\subsection{Molecular detection A(H1N1) 2009 virus}

Standardized protocols and external quality assurance panels were used to ensure validated specific and sensitive detection of A(H1N1) 2009 influenza virus by molecular methods as described by Meijer et al. (2009b). Briefly, purified total nucleic acid or RNA using LC Magnapure (Roche, Almere, The Netherlands) or EasyMag (Biomerieux, Zaltbommel, The Netherlands) was subjected to onestep or two-step real-time RT-PCR using a variety of cDNA synthesis chemistry, sample volume-equivalent RNA or cDNA input in PCR, PCR chemistry, and PCR platforms (Meijer et al., 2009b). Primers and probes and cycling conditions recommended in the protocols used by the central labs and distributed to the participating laboratories in The Netherlands are shown (Table 1). RT-PCR results from other laboratories were accepted as confirmed A(H1N1) 2009 after external quality assessment panels evaluated the performance of these laboratories as excellent for the detection and subtyping of $\mathrm{A}(\mathrm{H} 1 \mathrm{~N} 1) 2009$ virus as described (Meijer et al., 2009b).

\subsection{Virus isolation}

Virus isolation for phenotypic determination of antiviral susceptibility at the RIVM was initially performed at Biosafety Level (BSL)- 3 and then, after the virus was determined to be less virulent than originally thought, at BSL-2. Specimens that were positive for the A(H1N1) 2009 influenza virus were inoculated on tertiary monkey kidney cells (supplied by The Netherlands Vaccine Institute, Bilthoven, The 
Meijer, A., Jonges, M., Abbink, F., Ang, W., Beek, J. van, Beersma, M., Bloembergen, P., Boucher, C., Claas, E., Donker, G., Gageldonk-Lafeber, R. van, Isken, L., Jong, A. de, Kroes Leenders, S., Lubben, M. van der, Mascini, E., Niesters, B., Oosterheert, J.J., Osterhaus, A., Riesmeijer, R., Riezebos-Brilman, A., Schutten, M., Sebens, F., Stelma, F., Swaan, C., Timen, Alvel Veen, A. van 't, Vries, E. van der, Wierik, M. te, Koopmans, M. Oseltamivir-resistant pandemic $A(H 1 N 1) 2009$ influenza viruses detected through enhanced surveillance in the Netherlands, 2009-2010. Antiviral Research: 2011, 92(1), 81-89

Netherlands) or Madin Darby Canine Kidney I (MDCK-I) cells (kindly provided by Dr. G. van Meer, Utrecht University, The Netherlands), and maintained in culture for a maximum of 2 weeks or until cytopathic effect was observed. Confirmation of virus isolation was done by real-time RT-PCR as described above.

\subsection{Influenza antiviral drugs}

Oseltamivir carboxylate Ro64-0802 (GS4071) and zanamivir (GG167) were provided by Roche Diagnostics (Germany) and GlaxoSmithKline (United Kingdom), respectively.

\subsection{Phenotypic determination of antiviral susceptibility}

The phenotypic susceptibility of influenza virus isolates for oseltamivir and zanamivir was determined at the RIVM using a fluorescence- based NA inhibition assay and expressed as the concentration of NAI needed to inhibit the NA enzyme activity by 50\% (IC 50 ), as described elsewhere (Jonges et al., 2009; Potier et al., 1979). Briefly, $10 \mathrm{ll}$ virus equivalent to $30-40 \mathrm{nmol} / \mathrm{hr} / \mathrm{ml}$ NA enzyme activity in buffer (16.25 mM MES, $5 \mathrm{mM} \mathrm{CaCl}_{2}$ ) was mixed in a black 96-wells microtiter plate with $10 \mathrm{ll}$ of a 5-fold dilution series of oseltamivir or zanamivir (end concentrations 2000-0.001 nM in 12.5\% DMSO), and incubated for 30 min at 37 C. After addition of $30 \mathrm{ll}$ substrate (54.17 mM MES pH 6.5, 5 mM CaCl 2,170 lM 20-(4methylumbelliferyl)- a-o-N-acetylneuraminic acid sodium salt hydrate [MUNANA] [Sigma-Aldrich, United Kingdom]) the mix with an end concentration of $100 \mathrm{lM}$ MUNANA was incubated a further $60 \mathrm{~min}$ at 37 _C. The reaction was stopped by addition of $150 \mathrm{ll}$ of $0.1 \mathrm{M} \mathrm{NaOH}$ in $80 \%$ ethanol. Fluorescence was measured at 370 $\mathrm{nm}$ excitation and, $444 \mathrm{~nm}$ emission on a Fluoroskan Ascent fluorometer (Thermo Fisher Scientific, Landsmeer, The Netherlands).

\section{[TABLE 1]}

IC ${ }_{50}$ values were calculated using curve fitting implemented in GraphPad Prism version 4.00 for Windows (GraphPad Software, Inc., La Jolla, CA). Initially, A(H1N1) 2009 viruses were inactivated with Triton X-100 as described by Jonges et al. (2010). Briefly, virus culture supernatant was thoroughly mixed with Triton X100 (BDH Chemicals, Poole, United Kingdom) at a final concentration of 1\% (v/ v) and incubated at room temperature for 1 hour. As Triton X-100 did not adversely affect IC so $_{0}$ measurements (Jonges et al., 2010), inactivated virus was directly used in the phenotypic assay. Inactivation was omitted after the classification of the A(H1N1) 2009 virus was changed from BSL-3 to BSL-2. For a subset of viruses the susceptibility was determined at Erasmus Medical Center using the chemoluminescent NA-Star kit according to the instructions of the Manufacturer (Applied Biosystems, Nieuwerkerk aan de IJssel, The Netherlands), as described (Jonges et al., 2010).

\subsection{Genotypic determination H275Y substitution}

When it became clear that oseltamivir-resistant A(H1N1) 2009 viruses almost exclusively harbored the H275Y substitution in the NA, a real-time RT-PCR assay was set up that could detect the nucleotide substitution associated with this 
Meijer, A., Jonges, M., Abbink, F., Ang, W., Beek, J. van, Beersma, M., Bloembergen, P., Boucher, C., Claas, E., Donker, G., Gageldonk-Lafeber, R. van, Isken, L., Jong, A. de, Kroes Leenders, S., Lubben, M. van der, Mascini, E., Niesters, B., Oosterheert, J.J., Osterhaus, A., Riesmeijer, R., Riezebos-Brilman, A., Schutten, M., Sebens, F., Stelma, F., Swaan, C., Timen, Alvel Veen, A. van 't, Vries, E. van der, Wierik, M. te, Koopmans, M. Oseltamivir-resistant pandemic $A(H 1 N 1) 2009$ influenza viruses detected through enhanced surveillance in the Netherlands, 2009-2010. Antiviral Research: 2011, 92(1), 81-89

phenotype and determine the proportion of viruses carrying this substitution in the clinical specimen as described in detail by van der Vries et al.

(2010a). Real-time RT-PCR was carried out using the GeneAmp EZ rTth RNA PCR Kit (Applied Biosystems) and the primers and probes and cycling conditions are shown (Table 1). The protocol was distributed to laboratories in The Netherlands to allow rapid determination of this important substitution and adaptation of patient clinical management when needed.

\subsection{Sequencing}

Hemagglutinin 1 (HA1) (nt 8-789), NA (nt 669-1323), PB2 (nt 1684-2223), and full-length matrix genes were sequenced at the RIVM directly from clinical specimens using cycle-sequencing. RNA was purified from clinical specimens using the High Pure RNA Isolation Kit (Roche). cDNA was synthesized using Thermoscript Reverse Transcriptase Kit with the forward primer (Invitrogen, Leek, The Netherlands). PCR was performed using the HotStarTaq Mastermix Kit (Qiagen, Venlo, The Netherlands). After treatment of the amplicons with ExoSAP-IT (USB Corporation, Isogen Life Science, De Meern, The Netherlands), sequencing reactions were performed using the BigDye Terminator v3.1 Cycle Sequencing Kit (Applied Biosystems) and products were analyzed on an ABI 3700 sequencer (Applied Biosystems). All reactions were performed as recommended by the manufacturers of the kits. The primers and cycling conditions used are shown (Table 1). This protocol was shared with other laboratories that wanted to perform the sequencing themselves. NA and matrix sequences were used to monitor for NAI and adamantane antiviral susceptibility, respectively, and HA1, NA and PB2 fragments were used to compare resistant viruses with viruses of patients related in time of disease and in geographic region to monitor for possible spread of resistant strains. Sequences and results of antiviral susceptibility marker analysis carried out and made available by other laboratories in The Netherlands were included in the analysis. A subset of Dutch HA, NA, and PB2 sequences representative for the total set of more than 1100 viruses is available from the GISAID database (www.gisaid.

org), Accession No. EPI254455-EPI254527.

\subsection{Phylogenetic analysis}

Phylogenetic analysis was performed using BioNumerics software version 6.5 (Applied Maths, Gent, Belgium). The character data from a concatenated NA and PB2 fragments alignment or from an HA1 fragment alignment was used to build a maximum parsimony network using the Fitch method (Fitch, 1971) with a greedy tree construction algorithm, and random branch swapping was used to find the most optimal network topology. This method was chosen for its ability to link resistant influenza viruses to their suspected closest ancestor using a minimum number of "evolutionary events"' based on the simplest, most parsimonious explanation of an observation and as free as possible of specific evolutionary assumptions. The faithfulness of the entire network was determined by calculation of the global cophenetic correlation coefficient (Sokal and Rohlf, 1962). The significance of 
Meijer, A., Jonges, M., Abbink, F., Ang, W., Beek, J. van, Beersma, M., Bloembergen, P., Boucher, C., Claas, E., Donker, G., Gageldonk-Lafeber, R. van, Isken, L., Jong, A. de, Kroes Leenders, S., Lubben, M. van der, Mascini, E., Niesters, B., Oosterheert, J.J., Osterhaus, A., Riesmeijer, R., Riezebos-Brilman, A., Schutten, M., Sebens, F., Stelma, F., Swaan, C., Timen, Alvel Veen, A. van 't, Vries, E. van der, Wierik, M. te, Koopmans, M. Oseltamivir-resistant pandemic $A(H 1 N 1) 2009$ influenza viruses detected through enhanced surveillance in the Netherlands, 2009-2010. Antiviral Research: 2011, 92(1), 81-89

segregation of resistant influenza viruses was assessed by bootstrap analysis (500 iterations).

\subsection{Statistical analysis}

Box-and-whisker plot analysis, programmed in Windows Excel version 2007, was used to identify potential outliers for NAI susceptibility (Massart et al., 2005). IC50 values between 1.5 and 3 times the interquartile range (IQR) from the IQR boundaries, or more than three times the IQR from the IQR boundaries, were defined as mild or extreme outliers, respectively. After elimination of outliers, the remaining $\mathrm{IC}_{50}$ values were used to calculate the geometric mean IC ${ }_{50}$ S with $95 \%$ confidence intervals using GraphPad Prism software. Significance of differences between two geometric means was determined using an unpaired t-test implemented in GraphPad Prism, and $\mathrm{p}<0.05$ was considered significant.

\section{RESULTS}

\subsection{Virus detections}

The pandemic period in The Netherlands was characterized by two periods with peaks in A(H1N1) 2009 detections (Fig. 1A). From week 17/2009 through week $33 / 2009$, every single suspected case was investigated and treated with oseltamivir. Until week 26/2009, contacts were actively traced, offered oseltamivir prophylaxis, and investigated. If the contacts developed symptoms or were found positive, they were offered oseltamivir treatment. In week 33/ 2009, case finding was lifted. Virus detection reports from nonsentinel sources were subsequently derived mainly from mandatory notification of laboratory-confirmed hospitalized cases and confirmed cases that died. From then on, oseltamivir treatment was only recommended for severe cases and young children. Whereas in the first period only sporadic cases were found in the GP sentinel surveillance, during the epidemic period, as indicated by ILI consultation rates above the epidemic baseline threshold, sentinel as well as nonsentinel A(H1N1) 2009 detections peaked (Fig. 1A).

\subsection{Antiviral prescriptions}

In both periods of peak virus detections, prescriptions of oseltamivir peaked also (Fig. 1B). Zanamivir was only prescribed sporadically.

Most often it was used when oseltamivir therapy failed, and, most often, as intravenous treatment under license for compassionate use (e.g., van der Vries et al., 2010b).

\subsection{Antiviral resistance}

Overall, specimens of more than 1100 cases distributed across the pandemic period from week 17/2009 through week 20/2010 were included in the antiviral susceptibility analysis. Eighty-five specimens from sentinel surveillance cases and 894 from nonsentinel cases, mainly derived through active retrospective retrieval of diagnostic specimens following notification of confirmed hospitalized cases and confirmed cases that died, were sequenced at the RIVM. One hospital laboratory provided autonomously sequenced NA, HA, and PB2 fragments from 111 cases. In addition, an unknown number of specimens were analyzed by H275Y RT-PCR by 
Meijer, A., Jonges, M., Abbink, F., Ang, W., Beek, J. van, Beersma, M., Bloembergen, P., Boucher, C., Claas, E., Donker, G., Gageldonk-Lafeber, R. van, Isken, L., Jong, A. de, Kroes Leenders, S., Lubben, M. van der, Mascini, E., Niesters, B., Oosterheert, J.J., Osterhaus, A., Riesmeijer, R., Riezebos-Brilman, A., Schutten, M., Sebens, F., Stelma, F., Swaan, C., Timen, Alve Veen, A. van 't, Vries, E. van der, Wierik, M. te, Koopmans, M. Oseltamivir-resistant pandemic $A(H 1 N 1) 2009$ influenza viruses detected through enhanced surveillance in the Netherlands, 2009-2010. Antiviral Research: 2011, 92(1), 81-89

other laboratories of which only resistant results were reported and included in the analysis.

\section{[FIGURE 1]}

All 63 A(H1N1) 2009 viruses of which the matrix gene was sequenced harbored the S31N amino acid substitution characteristic of adamantane resistance. In total 19 patients were identified with oseltamivir-resistant virus harboring the H275Y amino acid substitution in the NA characteristic for oseltamivir resistance (14 by sequencing and 5 by H275Y RT-PCR). All these cases were identified during the epidemic period of A(H1N1) 2009 circulation in the autumn of 2009 and were derived from nonsentinel sources (Fig. 1A, inset). For the 18 cases that developed resistance under oseltamivir therapy, multiple samples were analyzed until the case was recovered or died within the study period. A first diagnostic specimen of these cases did not contain virus with the H275Y substitution.

The peak in the number of cases with resistant virus at week 48/2009 was 4 weeks delayed when compared to the peak in A(H1N1) 2009 detections at week 44/2009. One resistant case, following clearance of the H275Y variant under zanamivir therapy, subsequently developed reduced susceptibility to zanamivir (10- fold) and oseltamivir (46-fold) as determined by NA-Star chemiluminescent assay due to amino acid substitution I223R in the NA.

Details of this case have been described elsewhere (van der Vries et al., 2010b). Tracing and testing of ill contacts, hospital personnel as well as household and social contacts, of patients with resistant viruses did not reveal resistant virus in any of the specimens of these contacts. No resistant viruses were found among the tested sentinel surveillance viruses.

\subsection{Phenotypic evaluation of antiviral susceptibility}

Susceptibility levels of oseltamivir-sensitive seasonal A(H1N1) virus isolates from the latest season in which seasonal $\mathrm{A}(\mathrm{H} 1 \mathrm{~N} 1)$ viruses were dominant in The Netherlands (2007/2008) (Jonges et al., 2009) were compared with oseltamivirsensitive A(H1N1) 2009 virus isolates that were representative for the whole pandemic period (Fig. 2). Nine outliers were detected for which no explanation could be found in the NA sequence analysis. After removal of these outliers, the geometric mean $\mathrm{IC}_{50}$ values were calculated (Fig. 2). A(H1N1) 2009 viruses appeared to be 1.4fold more susceptible for oseltamivir and 2.0-fold more susceptible for zanamivir than the seasonal viruses. Although only one resistant A(H1N1) 2009 virus isolate was available for phenotypic testing, either because virus isolation was not successful due to low viral load or overgrowth by the sensitive virus in a mixed specimen, or because no specimen was left for virus isolation, this resistant virus was 2.9-fold more susceptible, when compared to the mean IC ${ }_{50}$ of oseltamivir resistant seasonal $\mathrm{A}(\mathrm{H} 1 \mathrm{~N} 1)$ viruses harboring the same $\mathrm{H} 275 \mathrm{Y}$ amino acid substitution.

\subsection{Characteristics of patients with resistant virus}

An aggregated description of demographic and clinical characteristics of the patients with resistant virus is shown (Table 2). 
Meijer, A., Jonges, M., Abbink, F., Ang, W., Beek, J. van, Beersma, M., Bloembergen, P., Boucher, C., Claas, E., Donker, G., Gageldonk-Lafeber, R. van, Isken, L., Jong, A. de, Kroes Leenders, S., Lubben, M. van der, Mascini, E., Niesters, B., Oosterheert, J.J., Osterhaus, A., Riesmeijer, R., Riezebos-Brilman, A., Schutten, M., Sebens, F., Stelma, F., Swaan, C., Timen, Alvel Veen, A. van 't, Vries, E. van der, Wierik, M. te, Koopmans, M. Oseltamivir-resistant pandemic $A(H 1 N 1) 2009$ influenza viruses detected through enhanced surveillance in the Netherlands, 2009-2010. Antiviral Research: 2011, 92(1), 81-89

The majority of the patients had a drug-induced immunosuppressed condition, a condition often resulting in prolonged shedding of virus. Because of this condition, prolonged therapy with antivirals was required. In addition, among the drug-induced immunosuppressed patients a substantial number had a hematologic disorder. Therefore, it is not surprising that resistance was induced by antiviral therapy in 18 of the 19 cases. In 10 cases, resistant virus was found at the end of the first course with oseltamivir or immediately at the beginning of the second course. In seven cases, oseltamivir resistance emerged during extended therapy with oseltamivir, and in one case at the end of the second course. Six of the patients represented in these cases died, of which four were still confirmed infected with the pandemic virus at 7 days before the day of death up to the day of death. In most of these cases, the cause of death was multifactorial to which the influenza virus infection may have contributed.

For one of the patients in our study, details were available that illustrate the importance of lymphocyte counts. This patient with acute lymphoblastic leukemia (ALL) on maintenance therapy was tested positive for the A(H1N1) 2009 influenza virus, which turned out to be oseltamivir-resistant after one course of oseltamivir following retrospective analysis. On return visit his X-ray was compatible with a diagnosis of a viral infection and he had severe lymphopenia $\left(0.06\right.$ _ $\left.10_{9} / \mathrm{L}\right)$. Therefore, chemotherapy of ALL was temporarily stopped and a second course of oseltamivir was given.

He became afebrile, gained weight, and his airway problems disappeared.

Because of the interruption of chemotherapy, his lymphocyte count rose again (0.56 _ $10 \mathrm{~g} / \mathrm{L}$ ) and thus, after 1 week, chemotherapy was restarted. About a month later, he was fit without respiratory symptoms except for mild rhinorrhea, and respiratory specimens were negative for A(H1N1) 2009 influenza virus, confirming clearance of the virus.

\section{[FIGURE 2]}

The patient in case 15 (Fig. 3) was a health care worker and was found to be infected with a resistant virus during a retrospective screening of viruses detected by the laboratory of the hospital where the health care worker was employed. This previously healthy person did not use oseltamivir and had not been exposed to infected persons using oseltamivir.

Fifteen of the patients represented in the 19 cases of oseltamivir- resistant virus stayed in the hospital under isolation while shedding resistant virus; four patients were not kept in isolation while shedding resistant virus.

\subsection{Phylogenetic analysis}

The maximum parsimony network of combined NA and PB2 sequences of which the topology was supported by a global cophenetic correlation coefficient of $94 \%$ showed that most resistant viruses were not clustered (Fig. 3). Except for the initial branching of case 19, which was supported by a bootstrap value of 35\%, branches leading to resistant strains were supported by a bootstrap value of $100 \%$. The resistant viruses of the case pairs $3 / 14$ and 6/19, which have an unknown common 
Meijer, A., Jonges, M., Abbink, F., Ang, W., Beek, J. van, Beersma, M., Bloembergen, P., Boucher, C., Claas, E., Donker, G., Gageldonk-Lafeber, R. van, Isken, L., Jong, A. de, Kroes Leenders, S., Lubben, M. van der, Mascini, E., Niesters, B., Oosterheert, J.J., Osterhaus, A., Riesmeijer, R., Riezebos-Brilman, A., Schutten, M., Sebens, F., Stelma, F., Swaan, C., Timen, Alvel Veen, A. van 't, Vries, E. van der, Wierik, M. te, Koopmans, M. Oseltamivir-resistant pandemic $A(H 1 N 1) 2009$ influenza viruses detected through enhanced surveillance in the Netherlands, 2009-2010. Antiviral Research: 2011, 92(1), 81-89

ancestor in the phylogenetic analysis (Fig. 3), developed during oseltamivir therapy and were distinct at a number of nucleic acid positions in the combined NA and PB2 sequence analysis. For case 19, sequences were available for two subsequent collection dates (Fig. 3).

\section{[TABLE 2]}

In addition to the nucleotide substitution resulting in the H275Y phenotype, the second specimen had a silent mutation in codon 426 in the NA. The cases in the case pairs were unrelated in time and/or place (hospital and residence) after epidemiologic evaluation. A similar phylogenetic analysis of the HA1 sequences did also not reveal any indication of correlation of the resistant viruses (not shown). The virus of the health care worker (case 15, Fig. 3), the only resistant case without known oseltamivir exposure, was not related to any of the other resistant viruses identified in patients from the same hospital (H1, Fig. 3), or from other hospitals per phylogenetic analysis.

\section{DISCUSSION}

As expected from previous studies on the emergence of antiviral resistance during oseltamivir therapy, we detected resistant viruses in oseltamivir-treated patients during the pandemic.

Similar to the situation before the 2007/2008 season in which NAI-resistant viruses were detected only sporadically in sentinel surveillance or in previously healthy persons (Jonges et al., 2009), we found just one previously healthy, untreated patient infected with an oseltamivir-resistant A(H1N1) 2009 virus for which no source could be identified. Although oseltamivir use was much higher than during previous seasons, which increased the risk for development of resistance, there is a possibility that prescribed oseltamivir was not actually used, but, rather stockpiled as a precaution, especially during the first few months of the pandemic (van den Wijngaard et al., 2009). Susceptible and oseltamivir-resistant A(H1N1) 2009 influenza viruses had slightly lower $\mathrm{IC}_{50}$ values for the NAIs than seasonal A(H1N1) influenza viruses, probably because of the different genetic backgrounds of the NA genes (Neumann et al., 2009).

Patient clinical diagnosis and follow-up data were only sparsely submitted with the specimens from nonsentinel sources. Even for the patients with resistant virus, it proved difficult to collect a comprehensive dataset retrospectively in the enhanced surveillance setting, as patients had already been dismissed or transferred to another hospital, or laboratory information management systems were not linked to patient records. Building a network of clinical laboratories and hospitals that can deliver timely critical information on the emergence of a new pathogen or pathogen with presumed altered virulence and linked clinical data could offer a solution, in line with WHO recommendations on the surveillance of severe acute respiratory infections (WHO, 2009b). Nevertheless, most of the required information for the 19 patients with resistant virus was finally obtained. The majority of the patients (84\%) in which we identified oseltamivir-resistant $A(H 1 N 1) 2009$ viruses were immunosuppressed because of an underlying condition or immunosuppressive 
Meijer, A., Jonges, M., Abbink, F., Ang, W., Beek, J. van, Beersma, M., Bloembergen, P., Boucher, C., Claas, E., Donker, G., Gageldonk-Lafeber, R. van, Isken, L., Jong, A. de, Kroes Leenders, S., Lubben, M. van der, Mascini, E., Niesters, B., Oosterheert, J.J., Osterhaus, A., Riesmeijer, R., Riezebos-Brilman, A., Schutten, M., Sebens, F., Stelma, F., Swaan, C., Timen, Milvel Veen, A. van 't, Vries, E. van der, Wierik, M. te, Koopmans, M. Oseltamivir-resistant pandemic $A(H 1 N 1) 2009$ influenza viruses detected through enhanced surveillance in the Netherlands, 2009-2010. Antiviral Research: 2011, 92(1), 81-89

therapy that resulted in prolonged virus shedding and therefore prolonged antiviral therapy. In the WHO review of January 12, 2011, and other available literature on oseltamivirresistant A(H1N1) 2009 influenza viruses, 30\% of resistant viruses were from immunosuppressed patients (WHO, 2011). However, as details of the patients' backgrounds slowly became available through publications, rather than through direct reports to the WHO, this percentage is likely an underestimation. NAI resistance has previously been found mostly in oseltamivir-treated children and immunosuppressed patients, which suggests that prolonged shedding of virus as seen in young children and in immunosuppressed patients is a favorable condition for such emergence (Dutkowski, 2010; Lackenby et al., 2008). Immunosuppressed patients frequently have lymphopenia, which might explain the lack of viral clearance. Restoration of lymphocyte counts positively influences viral clearance and the clinical outcome of immunosuppressed patients infected with influenza virus, irrespective of whether the virus has become resistant or not (Gooskens et al., 2009). In our current study, a similar observation was done in a patient with ALL, in whom oseltamivir therapy was combined with temporal cessation of chemotherapy. This subsequently led to restoration of lymphocyte counts and clearance of resistant influenza virus.

\section{[FIGURE 3]}

In addition, relative lymphopenia has been found to be an early and reliable laboratory finding of influenza virus type A infection in adults, underscoring the importance of lymphocyte responses in getting rid of influenza virus (Mohan et al., 2005). Further systematic research into combining NAI-antiviral therapy with immunomodulatory compounds is needed to elucidate whether severely ill patients suffering from influenza in general would benefit from such combination therapy. From a public health perspective, it was encouraging that we did not detect oseltamivir-resistant viruses in community-derived specimens or contacts of patients with resistant virus. This suggests that similar to seasonal $\mathrm{A}(\mathrm{H} 1 \mathrm{~N} 1)$ viruses before the 2007/ 2008 season, the H275Y substitution compromises the transmissibility of the $\mathrm{A}(\mathrm{H} 1 \mathrm{~N} 1) 2009$ virus and thus has so far had a limited public health impact.

However, the absence of transmission of resistant viruses in our study might be the cumulative effect of reduced viral shedding of the H275Y variant, isolation of most of the patients with resistant virus in a hospital, and prophylactic exposure measures for hospital personnel and visitors in contact with these patients. The potential of resistant A(H1N1) 2009 virus to spread has been proven by a cluster of 10 related patients in a hospital in Wales, UK, in which four patients were infected by the resistant virus through direct transmission (Moore et al., 2011).

Recently, resistant A(H1N1) 2009 viruses were detected in untreated patients in the UK during the 2010/2011 season (Lackenby et al., 2011). In addition, transmission experiments with H275Y A(H1N1) 2009 variants (Duan et al., 2010; Memoli et al., 2011; Seibert et al., 2010) showed efficient contact transmission, which underscores the continuous need for vigilance and monitoring for emergence of antiviral resistance in a public health setting by using, for example, sentinel influenza surveillance systems. Lack of human transmission might be explained, however, by 
Meijer, A., Jonges, M., Abbink, F., Ang, W., Beek, J. van, Beersma, M., Bloembergen, P., Boucher, C., Claas, E., Donker, G., Gageldonk-Lafeber, R. van, Isken, L., Jong, A. de, Kroes Leenders, S., Lubben, M. van der, Mascini, E., Niesters, B., Oosterheert, J.J., Osterhaus, A., Riesmeijer, R., Riezebos-Brilman, A., Schutten, M., Sebens, F., Stelma, F., Swaan, C., Timen, Milvel Veen, A. van 't, Vries, E. van der, Wierik, M. te, Koopmans, M. Oseltamivir-resistant pandemic $A(H 1 N 1) 2009$ influenza viruses detected through enhanced surveillance in the Netherlands, 2009-2010. Antiviral Research: 2011, 92(1), 81-89

the fact that introducing H275Y into the A/California/4/2009 (H1N1) 2009 virus caused a large drop in total surface-expressed NA activity (Bloom et al., 2010). In oseltamivir-resistant seasonal A(H1N1) viruses, R222Q and V234M substitutions in the NA were required for sustained transmissibility of viruses carrying H275Y (Bloom et al., 2010). The A(H1N1) 2009 viruses have 222N and 234V at these positions; however, the importance of these positions for restored surface expression of NA activity and sustained transmissibility of oseltamivir resistant A(H1N1) 2009 virus remains to be investigated.

In conclusion, the main associations in patients for the emergence of oseltamivirresistant pandemic A(H1N1) 2009 influenza virus were having had therapy with oseltamivir and having druginduced immunosuppression, or a hematologic disorder. Except for the single patient infected with resistant virus not linked to oseltamivir therapy, the absence of detection of resistant variants in community specimens and in specimens from contacts of patients with resistant virus suggests that emergence and subsequent spread of resistant $\mathrm{A}(\mathrm{H} 1 \mathrm{~N} 1) 2009$ virus was very limited, as a consequence of compromised NA activity of the H27Y-resistant variant, but possibly also as a result of patient isolation and effective exposure prophylaxis measures.

\section{ACKNOWLEDGEMENTS}

The authors thank Stichting Farmaceutische Kengetallen, Den Haag, The Netherlands, for providing commercial prescription data of antivirals and the Dutch Vaccine Institute, Bilthoven, The Netherlands, for prescription data of antivirals from the national stockpile during the A(H1N1) 2009 pandemic; Shireen Jenny, Piet Overduin, Mariam Bagheri, Ton Marzec, Yaobi Hu, Simone Boskamp, Ngoc Hoa Chung, Cheraine Paulsen, Frank den Oudsten from the RIVM and the many other technicians from other laboratories that contributed to this study for excellent technical assistance; the GPs, laboratory and hospital staff, workers from the municipal and regional health services, and all patients for providing information and specimens for investigation; and Susan T. Landry for editorial review.

\section{REFERENCES}

Alonso, T.V., Lozano Alonso, J.E., Ortiz de Lejarazu, R., Gutiérrez Pérez, M., 2004.

Modelling influenza epidemic - can we detect the beginning and predict the intensity and duration? Int. Congr. Ser. 1263, 281-283.

Basler, C.F., Aguilar, P.V., 2008. Progress in identifying virulence determinants of the 1918 $\mathrm{H} 1 \mathrm{~N} 1$ and the Southeast Asian H5N1 influenza A viruses. Antiviral Res. 79, 166-178.

Bloom, J.D., Gong, L.I., Baltimore, D., 2010. Permissive secondary mutations enable the evolution of influenza oseltamivir resistance. Science 328, 1272-1275.

Chan, C.H., Lin, K.L., Chan, Y., Wang, Y.L., Chi, Y.T., Tu, H.L., Shieh, H.K., Liu, W.T., 2006. Amplification of the entire genome of influenza $A$ virus $\mathrm{H} 1 \mathrm{~N} 1$ and $\mathrm{H} 3 \mathrm{~N} 2$ subtypes by reverse-transcription polymerase chain reaction. J. Virol. Methods 136, 38-43.

Chutinimitkul, S., Herfst, S., Steel, J., Lowen, A.C., Ye, J., van Riel, D., Schrauwen, E.J., Bestebroer, T.M., Koel, B., Burke, D.F., Sutherland-Cash, K.H., Whittleston, C.S., Russell, C.A., Wales, D.J., Smith, D.J., Jonges, M., Meijer, A., Koopmans, M., Rimmelzwaan, G.F., Kuiken, T., Osterhaus, A.D., García-Sastre, A., Perez, D.R., Fouchier, R.A., 2010. 
Meijer, A., Jonges, M., Abbink, F., Ang, W., Beek, J. van, Beersma, M., Bloembergen, P., Boucher, C., Claas, E., Donker, G., Gageldonk-Lafeber, R. van, Isken, L., Jong, A. de, Kroes Leenders, S., Lubben, M. van der, Mascini, E., Niesters, B., Oosterheert, J.J., Osterhaus, A., Riesmeijer, R., Riezebos-Brilman, A., Schutten, M., Sebens, F., Stelma, F., Swaan, C., Timen, Alve Veen, A. van 't, Vries, E. van der, Wierik, M. te, Koopmans, M. Oseltamivir-resistant pandemic $A(H 1 N 1) 2009$ influenza viruses detected through enhanced surveillance in the Netherlands, 2009-2010. Antiviral Research: 2011, 92(1), 81-89

Virulence-associated substitution D222G in the hemagglutinin of 2009 pandemic influenza $\mathrm{A}(\mathrm{H} 1 \mathrm{~N} 1)$ virus affects receptor binding. J. Virol. 84, 11802-11813.

Couzin-Frankel, J., 2009. Swine flu outbreak. What role for antiviral drugs? Science 324, 705.

Donker, G.A., 2011. Continuous Morbidity Registration at Dutch Sentinel General Practice Network 2009. Utrecht, The Netherlands, NIVEL, p. 183. Available from: <http://www.nivel.nl/oc2/page.asp?PagelD=15587\&path=/Startpunt/NIVEL>.

Duan, S., Boltz, D.A., Seiler, P., Li, J., Bragstad, K., Nielsen, L.P., Webby, R.J., Webster, R.G., Govorkova, E.A., 2010. Oseltamivir-resistant pandemic H1N1/2009 influenza virus possesses lower transmissibility and fitness in ferrets. PLoS Pathog. 6, e1001022.

Dutkowski, R., 2010. Oseltamivir in seasonal influenza: cumulative experience in low- and high-risk patients. J. Antimicrob. Chemother. 65 (Suppl. 2), ii11-ii24.

Fitch, W.M., 1971. Toward defining the course of evolution: minimum change for a specific tree topology. Syst. Zool. 20, 406-416.

Fleming, D.M., Elliot, A.J., Meijer, A., Paget, W.J., 2009. Influenza virus resistance to oseltamivir: what are the implications? Eur. J. Public Health 19, 238- 239.

Gooskens, J., Jonges, M., Claas, E.C., Meijer, A., Kroes, A.C., 2009. Prolonged influenza virus infection during lymphocytopenia and frequent detection of drugresistant viruses. J. Infect. Dis. 15, 1435-1441.

Gupta, Y.K., Padhy, B.M., 2010. Issues in pharmacotherapy of 2009 H1N1 influenza infection. J. Postgrad. Med. 56, 321-327.

Hahné, S., Donker, T., Meijer, A., Timen, A., van Steenbergen, J., Osterhaus, A., van der Sande, M., Koopmans, M., Wallinga, J., Coutinho, R.Dutch New Influenza A(H1N1)v Investigation Team, 2009. Epidemiology and control of influenza $A(H 1 N 1) v$ in the Netherlands: the first 115 cases. Euro Surveill. 14, pii: 19267.

Herfst, S., Chutinimitkul, S., Ye, J., de Wit, E., Munster, V.J., Schrauwen, E.J., Bestebroer, T.M., Jonges, M., Meijer, A., Koopmans, M., Rimmelzwaan, G.F., Osterhaus, A.D., Perez, D.R., Fouchier, R.A., 2010. Introduction of virulence markers in PB2 of pandemic swineorigin influenza virus does not result in enhanced virulence or transmission. J. Virol. 84, 3752-3758.

Jonges, M., van der Lubben, I.M., Dijkstra, F., Verhoef, L., Koopmans, M., Meijer, A., 2009. Dynamics of antiviral-resistant influenza viruses in the Netherlands, 2005-2008. Antiviral Res. 83, 290-297.

Jonges, M., Liu, W.M., van der Vries, E., Jacobi, R., Pronk, I., Boog, C., Koopmans, M., Meijer, A., Soethout, E., 2010. Influenza virus inactivation for studies of antigenicity and phenotypic neuraminidase inhibitor resistance profiling. J.

Clin. Microbiol. 48, 928-940.

Lackenby, A., Thompson, C.I., Democratis, J., 2008. The potential impact of neuraminidase inhibitor resistant influenza. Curr. Opin. Infect. Dis. 21, 626-638.

Lackenby, A., Moran Gilad, J., Pebody, R., Miah, S., Calatayud, L., Bolotin, S., Vipond, I., Muir, P., Guiver, M., McMenamin, J., Reynolds, A., Moore, C., Gunson, R., Thompson, C., Galiano, M., Bermingham, A., Ellis, J., Zambon, M., 2011.

Continued emergence and changing epidemiology of oseltamivir-resistant influenza A(H1N1)2009 virus, United Kingdom, winter 2010/11. Euro Surveill. 16, pii: 19784.

Lee, V.J., Lye, D.C., Wilder-Smith, A., 2009. Combination strategies for pandemic influenza response - a systematic review of mathematical modeling studies.

BMC Med. 7, 76.

Massart, D.L., Smeyers-Verbeke, J., Capron, X., Schlesier, K., 2005. Visual presentation of data by means of box plots. LC GC Europe 18, 215-218.

Meijer, A., Lackenby, A., Hay, A., Zambon, M., 2007. Influenza antiviral susceptibility monitoring activities in relation to national antiviral stockpiles in Europe during the winter 2006/2007 season. Euro Surveill. 12, E3-4. 
Meijer, A., Jonges, M., Abbink, F., Ang, W., Beek, J. van, Beersma, M., Bloembergen, P., Boucher, C., Claas, E., Donker, G., Gageldonk-Lafeber, R. van, Isken, L., Jong, A. de, Kroes Leenders, S., Lubben, M. van der, Mascini, E., Niesters, B., Oosterheert, J.J., Osterhaus, A., Riesmeijer, R., Riezebos-Brilman, A., Schutten, M., Sebens, F., Stelma, F., Swaan, C., Timen, Alvel Veen, A. van 't, Vries, E. van der, Wierik, M. te, Koopmans, M. Oseltamivir-resistant pandemic $A(H 1 N 1) 2009$ influenza viruses detected through enhanced surveillance in the Netherlands, 2009-2010. Antiviral Research: 2011, 92(1), 81-89

Meijer, A., Lackenby, A., Hungnes, O., Lina, B., van-der-Werf, S., Schweiger, B., Opp, M., Paget, J., van-de-Kassteele, J., Hay, A., Zambon, M.European Influenza Surveillance Scheme, 2009a. Oseltamivir-resistant influenza virus A (H1N1), Europe, 2007-08 season. Emerg. Infect. Dis. 15, 552-560.

Meijer, A., Beerens, A., Claas, E., Hermans, M., de Jong, A., Molenkamp, R., Niesters, H., Overduin, P., Rossen, J., Schuurman, R., Wolffs, P., Fouchier, R., Osterhaus, A., Schutten, M., Koopmans, M., 2009b. Preparing the outbreak assistance laboratory network in the Netherlands for the detection of the influenza virus A(H1N1) variant. J. Clin. Virol. 45, 179184.

Memoli, M.J., Davis, A.S., Proudfoot, K., Chertow, D.S., Hrabal, R.J., Bristol, T., Taubenberger, J.K., 2011. Multidrug-resistant 2009 pandemic influenza $A(H 1 N 1)$ viruses maintain fitness and transmissibility in ferrets. J. Infect. Dis.

203, 348-357.

Mohan, S.S., McDermott, B.P., Cunha, B.A., 2005. The diagnostic and prognostic significance of relative lymphopenia in adult patients with influenza A. Am. J.

Med. 118, 1307-1309.

Moore, C., Galiano, M., Lackenby, A., Abdelrahman, T., Barnes, R., Evans, M.R., Fegan, C., Froude, S., Hastings, M., Knapper, S., Litt, E., Price, N., Salmon, R., Temple, M., Davies, E., 2011. Evidence of person-to-person transmission of oseltamivirresistant pandemic influenza A(H1N1) 2009 virus in a hematology unit. J. Infect.

Dis. 203, 18-24.

Mounier-Jack, S., Coker, R.J., 2006. How prepared is Europe for pandemic influenza? Analysis of national plans. Lancet 367, 1405-1411.

Munster, V.J., Baas, C., Lexmond, P., Bestebroer, T.M., Guldemeester, J., Beyer, W.E., de Wit, E., Schutten, M., Rimmelzwaan, G.F., Osterhaus, A.D., Fouchier, R.A., 2009. Practical considerations for high-throughput influenza $A$ virus surveillance studies of wild birds by use of molecular diagnostic tests. J. Clin.

Microbiol. 47, 666-673.

Neumann, G., Noda, T., Kawaoka, Y., 2009. Emergence and pandemic potential of swineorigin H1N1 influenza virus. Nature 459, 931-939.

Patel, A., Gorman, S.E., 2009. Stockpiling antiviral drugs for the next influenza pandemic. Clin. Pharmacol. Ther. 86, 241-243.

Pel, J.Z.S., 1965. Proefonderzoek naar de frequentie en de aetiologie van griepachtige ziekten in de winter 1963-1964. Huisarts en Wetenschap 8, 321-324.

Potier, M., Mameli, L., Bélisle, M., Dallaire, L., Melançon, S.B., 1979. Fluorometric assay of neuraminidase with a sodium (4-methylumbelliferyl-alpha-D-Nacetylneuraminate) substrate. Anal. Biochem. 94, 287-296.

Rungrotmongkol, T., Intharathep, P., Malaisree, M., Nunthaboot, N., Kaiyawet, N., Sompornpisut, P., Payungporn, S., Poovorawan, Y., Hannongbua, S., 2009.

Susceptibility of antiviral drugs against 2009 influenza A (H1N1) virus.

Biochem. Biophys. Res. Commun. 385, 390-394.

Seibert, C.W., Kaminski, M., Philipp, J., Rubbenstroth, D., Albrecht, R.A., Schwalm, F., Stertz, S., Medina, R.A., Kochs, G., García-Sastre, A., Staeheli, P., Palese, P., 2010.

Oseltamivir-resistant variants of the 2009 pandemic H1N1 influenza A virus are not attenuated in the guinea pig and ferret transmission models. J. Virol. 84, 11219-11226. Sokal, R.R., Rohlf, F.J., 1962. The comparison of dendrograms by objective methods. Taxon 11, 33-40.

Taubenberger, J.K., Morens, D.M., 2006. 1918 Influenza: the mother of all pandemics. Emerg. Infect. Dis. 12, 15-22.

van Asten, L., van der Lubben, M., van den Wijngaard, C., van Pelt, W., Verheij, R., Jacobi, A., Overduin, P., Meijer, A., Luijt, D., Claas, E., Hermans, M., Melchers, W., Rossen, J., Schuurman, R., Wolffs, P., Boucher, C., Schirm, J., Kroes, L., Leenders, S., Galama, J., Peeters, M., van Loon, A., Stobberingh, E., Schutten, M., Koopmans, M., 2009. 
Meijer, A., Jonges, M., Abbink, F., Ang, W., Beek, J. van, Beersma, M., Bloembergen, P., Boucher, C., Claas, E., Donker, G., Gageldonk-Lafeber, R. van, Isken, L., Jong, A. de, Kroes Leenders, S., Lubben, M. van der, Mascini, E., Niesters, B., Oosterheert, J.J., Osterhaus, A., Riesmeijer, R., Riezebos-Brilman, A., Schutten, M., Sebens, F., Stelma, F., Swaan, C., Timen, Al IVel Veen, A. van 't, Vries, E. van der, Wierik, M. te, Koopmans, M. Oseltamivir-resistant pandemic $A(H 1 N 1) 2009$ influenza viruses detected through enhanced surveillance in the Netherlands, 2009-2010. Antiviral Research: 2011, 92(1), 81-89

Strengthening the diagnostic capacity to detect Bio Safety Level 3 organisms in unusual respiratory viral outbreaks. J. Clin. Virol. 45, 185-190.

van den Wijngaard, C.C., van Steenbergen, J.E., van der Sande, M.A., Koopmans, M.P.G., 2009. Nieuwe influenza $A$ (H1N1): geadviseerde indicatie en voorschrijfgedrag van antivirale middelen. Ned. Tijdschr. Geneeskd. 153, A1053.

van der Vries, E., Jonges, M., Herfst, S., Maaskant, J., Van der Linden, A., Guldemeester, J., Aron, G.I., Bestebroer, T.M., Koopmans, M., Meijer, A., Fouchier, R.A., Osterhaus, A.D., Boucher, C.A., Schutten, M., 2010a. Evaluation of a rapid molecular algorithm for detection of pandemic influenza A (H1N1) 2009 virus and screening for a key oseltamivir resistance (H275Y) substitution in neuraminidase. J. Clin. Virol. 47, 34-37.

van der Vries, E., Stelma, F.F., Boucher, C.A., 2010b. Emergence of a multidrugresistant pandemic influenza A (H1N1) virus. N. Engl. J. Med. 363, 1381-1382.

Ward, C.L., Dempsey, M.H., Ring, C.J., Kempson, R.E., Zhang, L., Gor, D., Snowden, B.W., Tisdale, M., 2004. Design and performance testing of quantitative real time PCR assays for influenza A and B viral load measurement. J. Clin. Virol. 29, 179-188.

World Health Organization, 2009a. World Now at the Start of 2009 Influenza Pandemic. Press Statement, Geneva, 11 June 2009. Available from: <http:// www.who.int/mediacentre/news/statements/2009/ h1n1_pandemic_phase6_20090611/en/index.html> (consulted 26.01.11).

World Health Organization, 2011. Update on Oseltamivir Resistance to Influenza H1N1 (2009) Viruses, 12 January 2011. Available from: <http://www.who.int/ csr/disease/influenza/ 2011_01_12_weekly_web_update_oseltamivir_resistance.pdf> (consulted 27.01.11).

World Health Organization Regional Office for Europe, 2009b. WHO Regional Office for Europe Guidance for Influenza Surveillance in Humans. Available from: $<$ http://www.euro.who.int/_data/assets/pdf_file/0020/90443/E9 2738.pdf> (consulted 04.02.11). 
Meijer, A., Jonges, M., Abbink, F., Ang, W., Beek, J. van, Beersma, M., Bloembergen, P., Boucher, C., Claas, E., Donker, G., Gageldonk-Lafelber, R. van, Isken, L., Jong, A. de, Kroes
Leenders, S., Lubben, M. van der, Mascini, E., Niesters, B., Oosterheert, J.J., Osterhaus, A., Riesmeijer, R., Riezebos-Brilman, A., Schutten, M., Sebens, F., Stelma, F., Swaan, C., Timen, Milve Veen, A. van 't, Vries, E. van der, Wierik, M. te, Koopmans, M. Oseltamivir-resistant pandemic $A(H 1 N 1) 2009$ influenza viruses detected through enhanced surveillance in the Netherlands, 2009-2010. Antiviral Research: 2011, 92(1), 81-89

\section{TABLES AND FIGURES:}

Table 1

Primers and probes used in the recommended protocols for detection of $\mathrm{A}(\mathrm{H} 1 \mathrm{~N} 1$ ) 2009 virus, for $\mathrm{H} 275 \mathrm{Y}$ single nucleotide polymorphism detection, and for sequencing of the HA, NA, PB2 and M genes of $A(H 1 N 1) 2009$ virus directly from clinical specimens.

\begin{tabular}{|c|c|c|c|}
\hline Name & Target ${ }^{2}$ & Sequence $5^{\prime}-3^{\prime}$ & Reference \\
\hline \multicolumn{4}{|c|}{ Two-step real-time RT-PCR detection assay RIVM ${ }^{\mathrm{b}}$} \\
\hline INFAM-Sense2 & $\mathrm{M}$ & AAGACCAATCYTGTCACCTCTGA & This study \\
\hline INFAM-a-Sense & M & CAAAGCGTCTACGCTGCAGTCC & Ward et al. (2004) \\
\hline INFAM-probe2 & M & FAM-TTTGTGTTCACGCTCACCGTGCC-BHQ1 & Munster et al. (2009) \\
\hline $\mathrm{H} 1-\mathrm{SW}-1304 \mathrm{~F}$ & H1 2009 & TTTGGACTTACAATGCCG & Meijer et al. (2009b) \\
\hline $\mathrm{H} 1-\mathrm{SW}-1410 \mathrm{R}$ & H1 2009 & TAGCTGGCTICTTACCT & Meijer et al. (2009b) \\
\hline H1-SW-1357P & H1 2009 & Texas Red-GACTACCACGATTCAAATGTGAAGA-BHQ1 & Meijer et al. (2009b) \\
\hline N1-SW-1111F2 & N1 2009 & TITGAGATGATYTGGGATC & This study \\
\hline N1-1142Rv & N1 2009 & AAAACTCCCGCTATATC & This study \\
\hline N11177P & N1 2009 & FAM-ATCGTAGGAATAAATGAGTGG-HBQ1 & This study \\
\hline \multicolumn{4}{|c|}{ One-step real-time RT-PCR detection assay Erasmus Medical Centre ${ }^{\epsilon}$} \\
\hline InfA-sense-TM & $\mathrm{M}$ & AAGACCAATCCTGTCACCTCTGA & Ward et al. (2004) \\
\hline InfA-antisense-TM & M & CAAAGCGTCTACGCTGCAGTCC & Ward et al. (2004) \\
\hline InfA-probe-2 & M & FAM-TTTGTGTTCACGCTCACCG TGCC-BHQ1 & Munster et al. (2009) \\
\hline panH1-forward & H1 2009 & GGAAAGAAATGCTGGATCTGGTA & van der Vries et al. (2010a) \\
\hline panH1-reverse & H1 2009 & ATGGGAGGATGGTGTTTATAGC & van der Vries et al. (2010a) \\
\hline panH1-probe & H1 2009 & Dragonfly-TGCAATACAACTTGTCAGACACCCAAGGG-BHQ2 & van der Vries et al. (2010a) \\
\hline MexFluN1-fwd & N1 2009 & ACATGTGTGTGCAGGGATAACTG & Meijer et al. (2009b) \\
\hline MexFluN1-rev & N1 2009 & TCCGAAAATCCCACTGCATAT & Meijer et al. (2009b) \\
\hline MexFluN1-probe & N1 2009 & FAM-ATCGACCGTGGGTGTCTITCAACCA-BHQ1 & Meijer et al. (2009b) \\
\hline \multicolumn{4}{|c|}{ H275Y RT-PCR assay Erasmus Medical Centre ${ }^{d}$} \\
\hline panN1-H275-sense & N1 2009 & CAGTCGAAATGAATGCCCCTAA & van der Vries et al. (2010a) \\
\hline panN1-H275-antisense & N1 2009 & TGCACACACATGTGATTTCACTAG & van der Vries et al. (2010a) \\
\hline panN1-275H-probe & N1 2009 & FAM-TTAtcaCTaTG aGGAATG-BHQ1 ${ }^{\circ}$ & van der Vries et al. (2010a) \\
\hline panN1-275Y-probe & N1 2009 & Dragonfly-TTAttaCTaTGaGGAATG-BHQZe & van der Vries et al. (2010a) \\
\hline \multicolumn{4}{|l|}{ Sequencing RIVM ${ }^{f}$} \\
\hline M $1 F$ & M & AGCAAAAGCAGGTAGATATT & Chan et al. (2006) \\
\hline M $1027 \mathrm{R}$ & M & AGTAG AAACAAGGTAGTTTTT & Chan et al. (2006) \\
\hline $\mathrm{H} 144 \mathrm{~F}$ & H1 2009 & CAAATGCAGACACATTAT & This study \\
\hline H1 864R & H1 2009 & TGGTGTATCTGAAATGATAAT & This study \\
\hline H1 785R & H1 2009 & GTTGCTTTGAATGTTATT & This study \\
\hline N1 $649 \mathrm{~F}$ & N1 2009 & AAGAGTTGGAGAAACAATAT & This study \\
\hline N1 $1341 R$ & N1 2009 & ACCACAAAAGGATATGCT & This study \\
\hline N1 $1280 R$ & N1 2009 & ATTAGTTCAACCCAGAAG & This study \\
\hline PB2 1666F & PB2 2009 & AACTGGGAAATTGTGAAA & This study \\
\hline PB2 2242R & PB2 2009 & GGCTGTCAGTAAGTATGCT & This study \\
\hline PB2 2210R & PB2 2009 & CGTTTCATTACCAACACTA & This study \\
\hline
\end{tabular}

2 M: matrix gene specific for all influenza A viruses; H1 2009: hemagglutinin gene coding for H1 of A(H1N1) 2009 virus; N1 2009: neuraminidase gene coding for N1 of A(H1N1) 2009 virus; PB2 2009: PB2 gene coding for PB2 of $A(H 1 N 1) 2009$.

${ }^{b}$ AMV Reverse Transcription Kit (Promega, Leiden, The Netherlands) with random hexamers for cDNA step ( $944^{\circ} \mathrm{C} 2$ min RNA denaturation; cDNA synthesis room temperature $10 \mathrm{~min} ; 42^{\circ} \mathrm{C} 50 \mathrm{~min} ; 94^{\circ} \mathrm{C} 2 \mathrm{~min}$ ) and LightCycler Taqman Master Kit (Roche) for PCR step $\left(95^{\circ} \mathrm{C} 10 \mathrm{~min} ; 94{ }^{\circ} \mathrm{C} 10 \mathrm{~s}, 50^{\circ} \mathrm{C} 20 \mathrm{~s}, 72^{\circ} \mathrm{C} 10 \mathrm{~s}\right.$ for $45 \mathrm{cydes}$ ).

${ }^{c}$ GeneAmp EZ rTth RNA PCR Kit (Applied Biosystems) $\left(50^{\circ} \mathrm{C} 2 \mathrm{~min} ; 60^{\circ} \mathrm{C} 30 \mathrm{~min} ; 95^{\circ} \mathrm{C} 5 \mathrm{~min} ; 95^{\circ} \mathrm{C} 20 \mathrm{~s}, 62{ }^{\circ} \mathrm{C} 1 \mathrm{~min}\right.$ for 45 cycles)

${ }^{\circ}$ GeneAmp EZ rTth RNA PCR Kit (Applied Biosystems) $\left(50{ }^{\circ} \mathrm{C} 2 \mathrm{~min} ; 60^{\circ} \mathrm{C} 30 \mathrm{~min} ; 95{ }^{\circ} \mathrm{C} 5 \mathrm{~min} ; 95^{\circ} \mathrm{C} 20 \mathrm{~s}, 60^{\circ} \mathrm{C} 1 \mathrm{~min}\right.$ for 45 cycles).

- LNA nucleotides are displayed in lower case and DNA nucleotides in upper case. LNA nucleotides complementary to the predicted single nucleotide polymorphism leading to the $\mathrm{H} 275 \mathrm{Y}$ amino adid substitution are underlined.

${ }^{t}$ Thermoscript Reverse Transcriptase Kit (Invitrogen) with forward primer for cDNA step $\left(95^{\circ} \mathrm{C} 5\right.$ min RNA denaturation; $c D N A$ synthesis $65^{\circ} \mathrm{C} 60$ min; $85^{\circ} \mathrm{C} 5$ min), HotStarTaq Mastermix Kit (Qiagen) for PCR step $\left(95^{\circ} \mathrm{C} 15 \mathrm{~min} ; 94^{\circ} \mathrm{C} 30 \mathrm{~s}, 50^{\circ} \mathrm{C} 30 \mathrm{~s}, 72{ }^{\circ} \mathrm{C} 1 \mathrm{~min}\right.$ for $\left.45 \mathrm{cycles} ; 72^{\circ} \mathrm{C} 10 \mathrm{~min}\right)$, and BigDye Terminator v3.1 Cyde Sequencing Kit (Applied Biosystems) for sequencing reaction $\left(96^{\circ} \mathrm{C} 10 \mathrm{~s} ; 96{ }^{\circ} \mathrm{C} 10 \mathrm{~s}, 50^{\circ} \mathrm{C} 5 \mathrm{~s}, 60^{\circ} \mathrm{C} 4 \mathrm{~min}\right.$ for $25 \mathrm{cycles}$ ). 
Meijer, A., Jonges, M., Abbink, F., Ang, W., Beek, J. van, Beersma, M., Bloembergen, P., Boucher, C., Claas, E., Donker, G., Gageldonk-Lafeber, R. van, Isken, L., Jong, A. de, Kroes Leenders, S., Lubben, M. van der, Mascini, E., Niesters, B., Oosterheert, J.J., Osterhaus, A., Riesmeijer, R., Riezebos-Brilman, A., Schutten, M., Sebens, F., Stelma, F., Swaan, C., Timen, Milve V Veen, A. van 't, Vries, E. van der, Wierik, M. te, Koopmans, M. Oseltamivir-resistant pandemic $A(H 1 N 1) 2009$ influenza viruses detected through enhanced surveillance in the Netherlands, 2009-2010. Antiviral Research: 2011, 92(1), 81-89

(A)

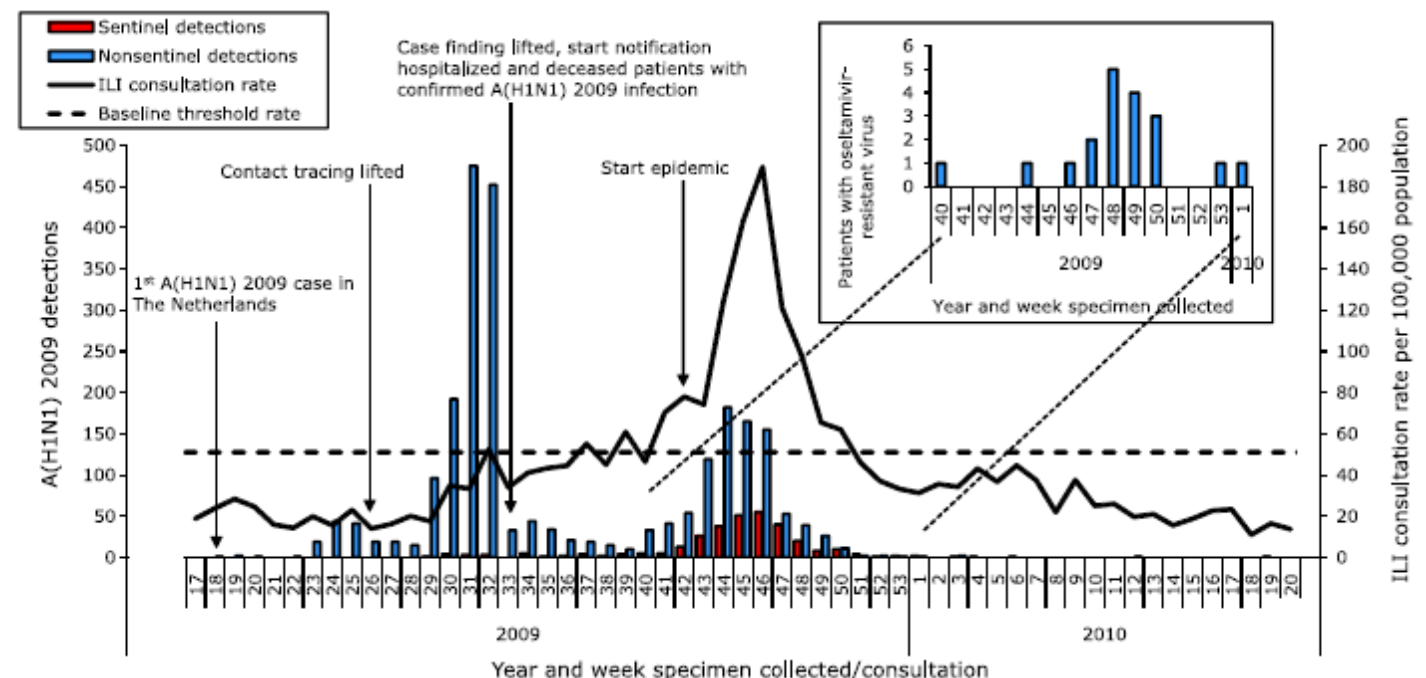

(B)

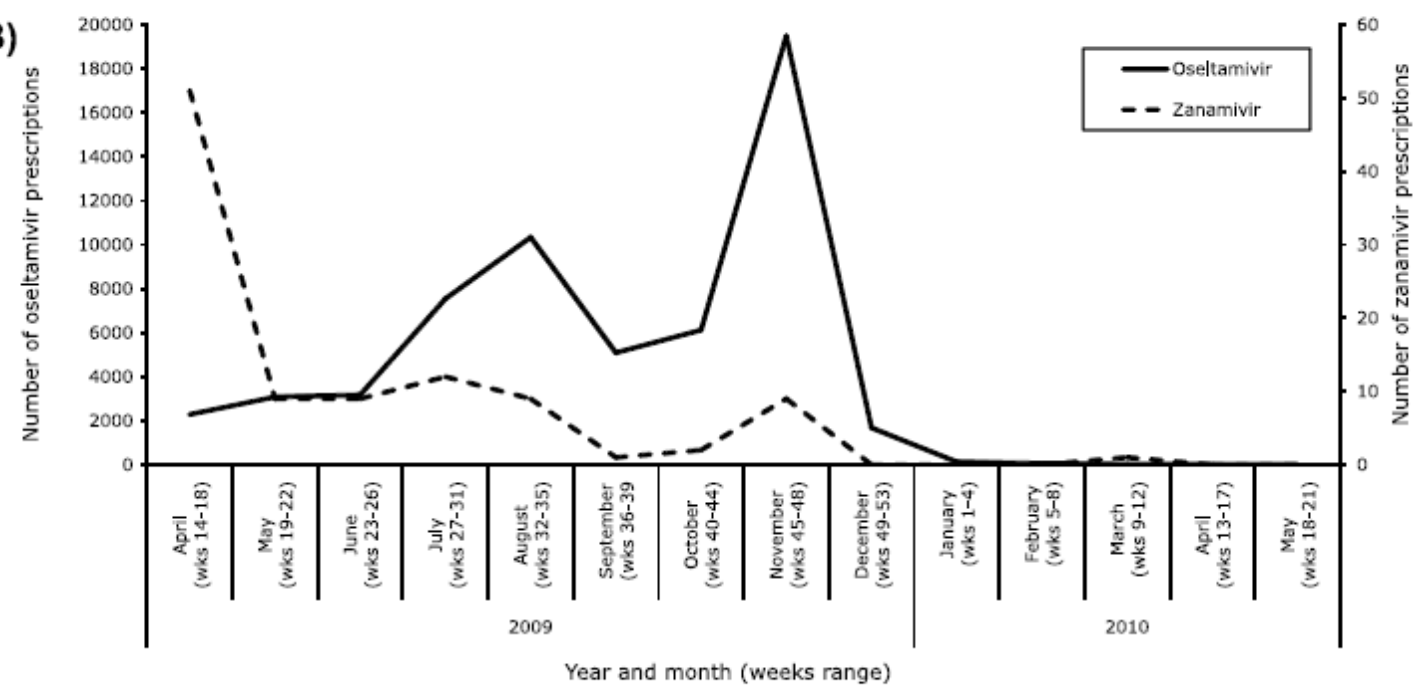

Fig. 1. Timing of detection of patients with oseltamivir-resistant (H275Y) A(H1N1) 2009 viruses (A, inset) in the pandemic period in The Netherlands (A), and the relation to prescriptions of oseltamivir and zanamivir in The Netherlands (B). The 19 patients with resistant virus ( $\mathrm{A}$, inset), detected from nonsentinel sources (blue bars in $\mathrm{A}$ and $\mathrm{A}$, inset), are plotted on the week the first specimen with resistant virus was collected. This explains the delay of a couple of weeks between the week of peak detection of resistant viruses and the weeks of peak diagnostic virus detections and peak influenza-like illness (ILI) consultation ratio. No resistant viruses were found in the general practice sentinel surveillance (red bars in A). Peaks in virus detections (A) coincided roughly with prescriptions of oseltamivir (B). 
Meijer, A., Jonges, M., Abbink, F., Ang, W., Beek, J. van, Beersma, M., Bloembergen, P., Boucher, C., Claas, E., Donker, G., Gageldonk-Lafeber, R. van, Isken, L., Jong, A. de, Kroes $A$ Leenders, S., Lubben, M. van der, Mascini, E., Niesters, B., Oosterheert, J.J., Osterhaus, A., Riesmeijer, R., Riezebos-Brilman, A., Schutten, M., Sebens, F., Stelma, F., Swaan, C., Timen, Milve Veen, A. van 't, Vries, E. van der, Wierik, M. te, Koopmans, M. Oseltamivir-resistant pandemic $A(H 1 N 1) 2009$ influenza viruses detected through enhanced surveillance in the Netherlands, 2009-2010. Antiviral Research: 2011, 92(1), 81-89
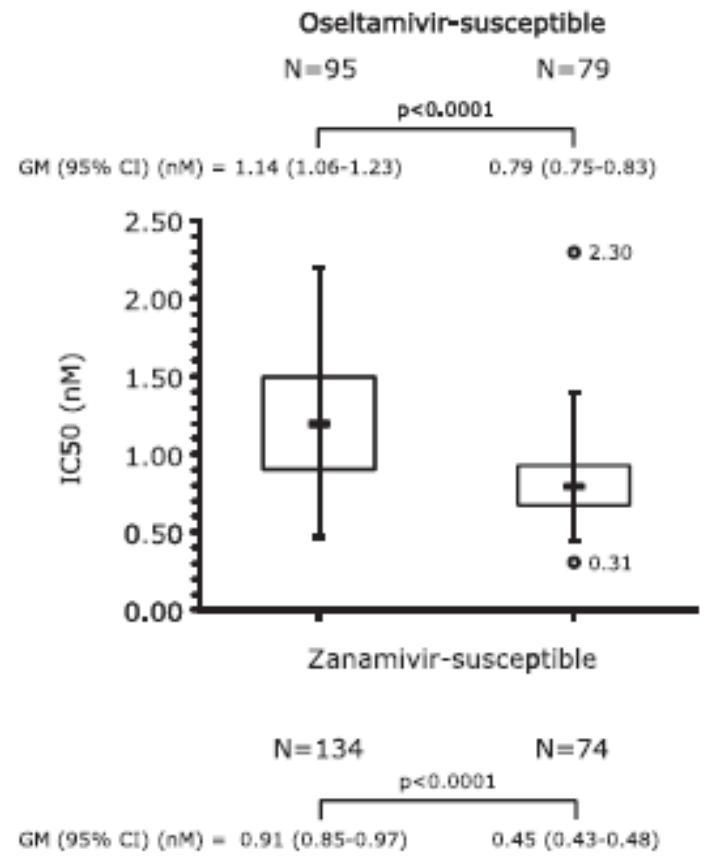

$\mathrm{GM}(95 \% \mathrm{Cr})(\mathrm{nM})=0.91(0.85-0.97) \quad 0.45(0.43-0.48)$

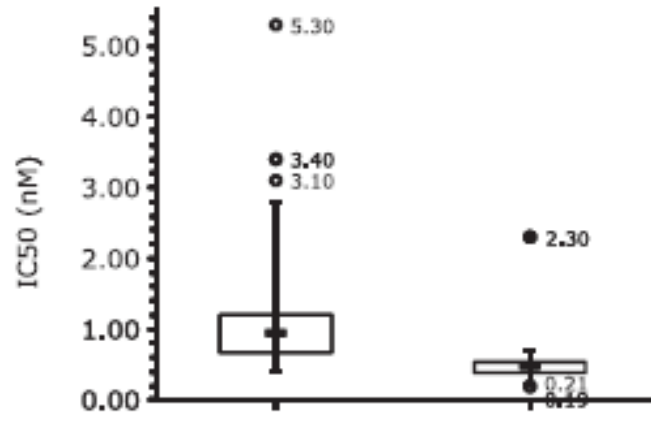

Oseltamivir-resistant (H275Y)

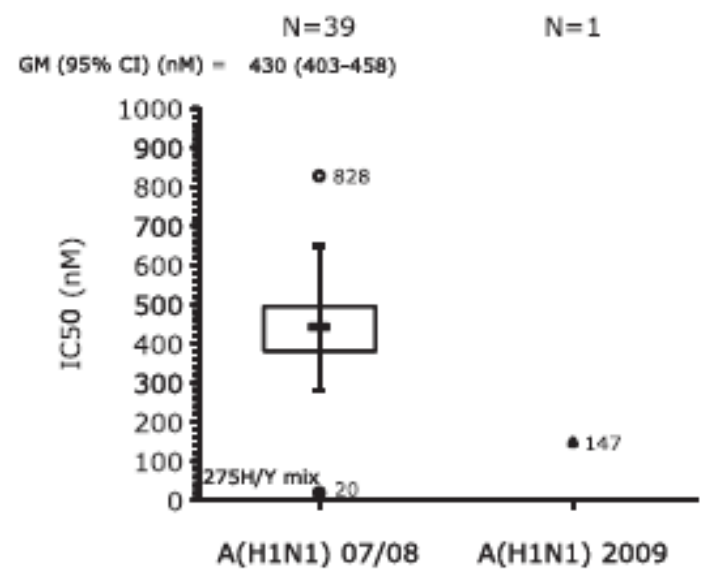

Fig. 2. Box-and-whisker plots showing $\mathrm{IC}_{50}$ values for oseltamivir-susceptible andresistant and zanamivir-susceptible seasonal $A(H 1 N 1) 2007 / 2008$ and pandemic A(H1N1) 2009 influenza viruses, from The Netherlands. Closed and open cirdes represent mild and extreme outliers, respectively. GM $(95 \% \mathrm{Cl})=$ the geometric mean of $\mathrm{IC}_{50}$ values after removal of outliers, with the $95 \%$ confidence interval indicated in brackets. The significance of the difference between two geometric means is indicated by the p-value of the unpaired $t$-test. 
Meijer, A., Jonges, M., Abbink, F., Ang, W., Beek, J. van, Beersma, M., Bloembergen, P., Boucher, C., Claas, E., Donker, G., Gageldonk-Lafeber, R. van, Isken, L., Jong, A. de, Kroes A Leenders, S., Lubben, M. van der, Mascini, E., Niesters, B., Oosterheert, J.J., Osterhaus, A., Riesmeijer, R., Riezebos-Brilman, A., Schutten, M., Sebens, F., Stelma, F., Swaan, C., Timen, Milvel Veen, A. van 't, Vries, E. van der, Wierik, M. te, Koopmans, M. Oseltamivir-resistant pandemic $A(H 1 N 1) 2009$ influenza viruses detected through enhanced surveillance in the Netherlands, 2009-2010. Antiviral Research: 2011, 92(1), 81-89

Table 2

Main characteristics of patients with oseltamivir-resistant A(H1N1) 2009 virus, in The Netherlands.

\begin{tabular}{ll}
\hline Characteristic & $\begin{array}{l}\text { Number } \\
(N-19)\end{array}$ \\
\hline Gender (male) & $10(53 \%)$ \\
Age (years; mean, range) & $35(1-69)$ \\
Hospitalized while shedding resistant virus & $15(79 \%)$ \\
Immunosuppressed & $16(84 \%)^{\mathrm{a}}$ \\
Hematologic disorder (HD) & $11(58 \%)$ \\
No allogenic stem cell transplantation & $5(45 \%$ of HD) \\
$\quad$ Non-Hodgkin lymphoma & 2 \\
Leukemia (any form) & 3 \\
Post allogenic stem cell transplantation & $6(55 \%$ of HD) \\
Leukemia (any form) & 3 \\
Aplastic anemia & 1 \\
$\quad$ Unknown underlying disease & 2 \\
Oseltamivir therapy induced & $18(95 \%)$ \\
Days (mean, range) between onset respiratory illness & $17(5-68)^{\mathrm{b}}$ \\
$\quad$ and last positive specimen & $11(5-27)^{\mathrm{b}}$ \\
Days (mean, range) between onset respiratory illness & \\
and first detection resistance & $6(32 \%)^{\mathrm{c}}$ \\
Death & $31(3-109)$ \\
Days (mean, range) between first detection resistance & \\
and death & \\
\hline
\end{tabular}

a Immunosuppressed due to treatment with cytostatic or immunosuppressive drugs or drugs with an immunosuppressive side effect. The three not immunosuppressed patients were a male of age 57 suffering from liver disease, a girl of age 1 undergoing Blalock-Taussig shunt surgery, and a healthy female of age 46.

b The single patient who was infected with resistant virus is exduded

${ }^{c}$ Four patients were still confirmed infected with $\mathrm{A}$ (H1N1) 2009 virus 0-7 days before the day of death. Five patients received cytostatic or immunosuppressive drugs. 
Meijer, A., Jonges, M., Abbink, F., Ang, W., Beek, J. van, Beersma, M., Bloembergen, P., Boucher, C., Claas, E., Donker, G., Gageldonk-Lafeber, R. van, Isken, L., Jong, A. de, Kroes A Leenders, S., Lubben, M. van der, Mascini, E., Niesters, B., Oosterheert, J.J., Osterhaus, A., Riesmeijer, R., Riezebos-Brilman, A., Schutten, M., Sebens, F., Stelma, F., Swaan, C., Timen, Dilvel Veen, A. van 't, Vries, E. van der, Wierik, M. te, Koopmans, M. Oseltamivir-resistant pandemic $A(H 1 N 1) 2009$ influenza viruses detected through enhanced surveillance in the Netherlands, 2009-2010. Antiviral Research: 2011, 92(1), 81-89

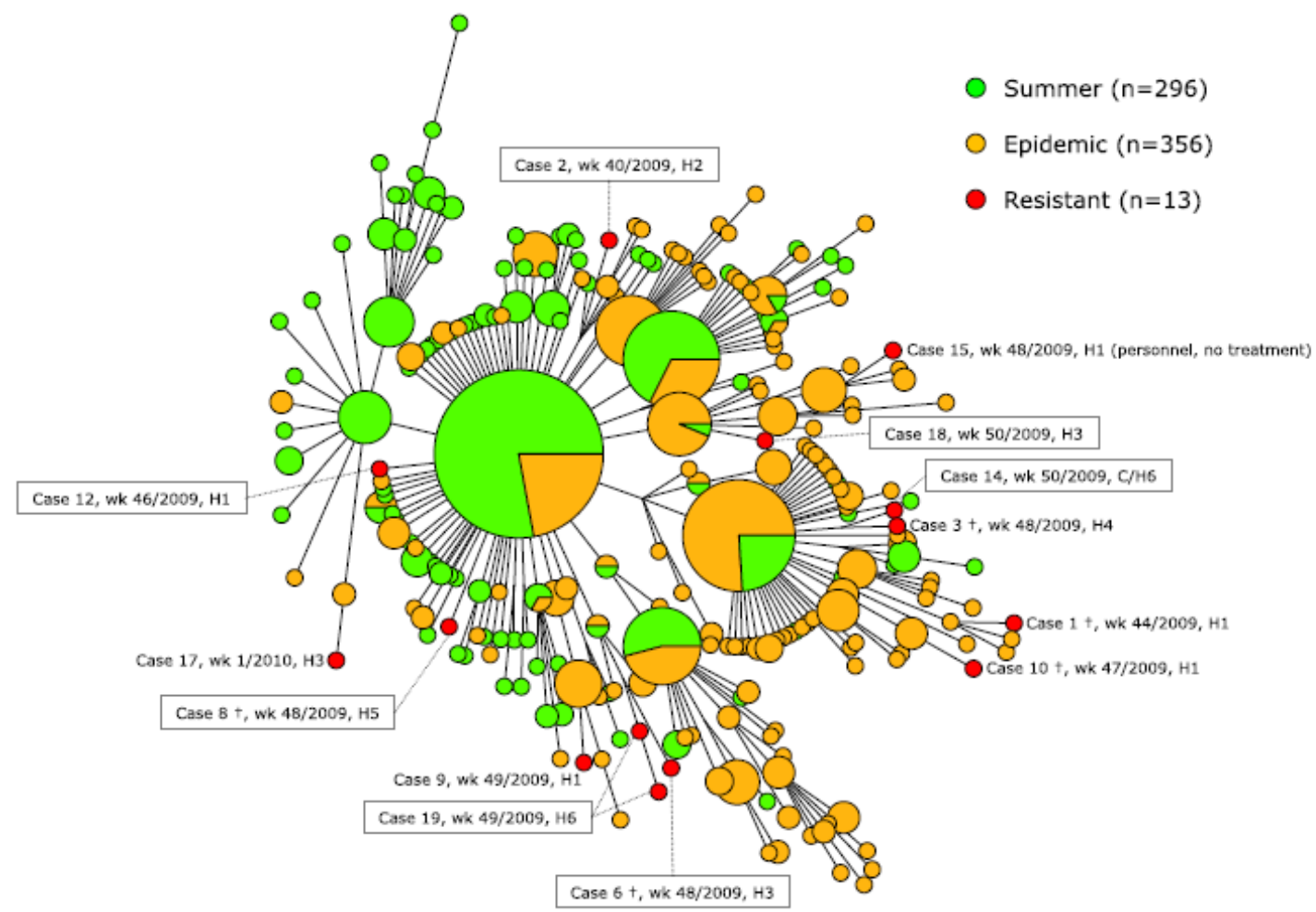

Fig. 3. Phylogenetic network infer red using maximum parsimony showing relationships of combined NA and PB2 sequences of 13 cases with resistant $A(H 1 N 1) 2009$ virus (case \#, † = deceased, wk ww/yyyy - week and year of first detection resistant virus, H\# = originating hospital, C = community) with cmbined NA and PB2 sequences of other A(H1N1) 2009 viruses from the enhanced surveillance, in The Netherlands. The topology of the network was supported by a global cophenetic correlation coefficient of $94 \%$. Except for the initial branching of case 19 (bootstrap value of $35 \%$ ), all branches leading to resistant viruses were supported by a bootstrap value of $100 \%$ after 500 iterations. The diameter of the circles represents the number of identical sequences with the smallest circle representing just one virus. The distance between cirdes represents the number of nudeotide substitutions with the smallest distances representing just one nucleotide substitution. 